\title{
Human Histocompatibility Leukocyte Antigen-binding Supermotifs Predict Broadly Cross-reactive Cytotoxic T Lymphocyte Responses in Patients with Acute Hepatitis
}

\author{
Roberto Bertoni, ${ }^{\star}$ John Sidney, ${ }^{\ddagger}$ Patricia Fowler, ${ }^{*}$ Robert W. Chesnut, ${ }^{\ddagger}$ Francis V. Chisari, ${ }^{\star}$ and Alessandro Sette ${ }^{\ddagger}$ \\ *Department of Molecular and Experimental Medicine, The Scripps Research Institute, La Jolla, California 92037; and ${ }^{\ddagger}$ Department of \\ Immunology, Cytel Corporation, San Diego, California 92121
}

\begin{abstract}
The present study was designed to determine if highly conserved hepatitis B virus (HBV)-derived peptides that bind multiple HLA class I alleles with high affinity are recognized as cytotoxic T lymphocyte (CTL) epitopes in acutely infected patients. Peripheral blood mononuclear cells from 67 patients with acute hepatitis $B$, and 12 patients convalescent from acute hepatitis B, were stimulated with three panels of peptides, each of which bind with high affinity to several class I alleles from the HLA-A2-, HLA-A3-, or HLA-B7-supertypes. In these patients, 8 of the 19 peptides tested were found to represent CTL epitopes recognized by two or more alleles in each supertype. Two sets of nested peptides were recognized in the context of alleles with completely unrelated peptide binding specificities. Finally, promiscuous recognition by the same CTL of a given peptide presented by target cells expressing different A2 subtypes was also commonly observed. In conclusion, several HBV-specific CTL epitopes, recognized by acutely infected or convalescent patients in the context of a wide range of HLA alleles have been identified. These results demonstrate the functional relevance of the supertype grouping of HLA class I molecules in a human viral disease setting. Furthermore, they represent a significant advance in the development of a totally synthetic vaccine to terminate chronic HBV infection and support the feasibility of a systematic approach to development of similar vaccines for prevention and treatment of other chronic viral infections. (J. Clin. Invest. 1997. 100:503-513.) Key words: hepatitis B virus • cytotoxic T lymphocytes $•$ chronic hepatitis • immunotherapy $\bullet$ HLA class I supermotifs
\end{abstract}

\section{Introduction}

Analysis of the class I restricted cytotoxic $\mathrm{T}$ lymphocyte $(\mathrm{CTL})^{1}$ response to viruses that cannot be propagated in cell

Address correspondence to Francis V. Chisari, M.D., Department of Molecular and Experimental Medicine, The Scripps Research Institute, 10550 North Torrey Pines Rd., La Jolla, CA 92037. Phone: 619784-8228; FAX: 619-784-2160; E-mail: fchisari@scripps.edu

Received for publication 25 February 1997 and accepted in revised form 22 April 1997.

1. Abbreviations used in this paper: ALT, alanine amino transferase; CTL, cytotoxic T lymphocytes; HBsAg, hepatitis B surface antigen; $\mathrm{HBV}$, hepatitis B virus.

J. Clin. Invest.

(C) The American Society for Clinical Investigation, Inc. 0021-9738/97/08/0503/11 \$2.00

Volume 100, Number 3, August 1997, 503-513

http://www.jci.org culture has depended on the in vitro stimulation of memory CTL with synthetic viral peptides. Initially, peptides chosen at random from the amino acid sequence of candidate hepatitis $B$ virus (HBV) proteins led to the identification of CTL responses to several viral epitopes restricted by $\operatorname{HLA}-\mathrm{A} 2(1,2)$, and HLA-A31 and HLA-Aw68 (3), in acutely infected patients, and demonstrated that similar CTL responses were weak or undetectable in patients with chronic HBV infection (4). Identification of the HLA-A2 binding motif (5-7) greatly facilitated HBV epitope identification studies in infected patients (8), normal volunteers (9), and HLA-A2 transgenic mice (10). These studies led to the demonstration that the CTL response to HBV persists indefinitely after clinical recovery from acute hepatitis (11) and that it also becomes detectable after resolution of chronic HBV infection (12). Use of HLA specific motifs has led to identification of epitopes from other viruses, such as hepatitis C virus (13-17), HIV (18), influenza $(19,20)$ and human papillomavirus $(21)$, as well as tumor antigens (22-24).

Development of quantitative HLA-binding assays identified a remarkable association between the strength of binding and the immunogenicity of individual peptides in patients and HLA transgenic mice (10). The recent discovery that multiple class I alleles can recognize common sequence motifs (supermotifs) led to the identification of groups of alleles (supertypes) that recognize similar motifs (25-29). For example, members of the HLA-A2-supertype bind short peptides containing one of the following residues ( $\mathrm{L}, \mathrm{V}, \mathrm{M}, \mathrm{I}, \mathrm{T}$, or A) at position 2 and at the carboxy-terminus. In contrast, molecules of the HLA-A3-supertype recognize A, I, L, M, V, S, or T at position 2 and either $\mathrm{R}$ or $\mathrm{K}$ at the $\mathrm{COOH}$ terminus; the $\mathrm{B} 7$ supertype recognizes peptides with $\mathrm{P}$ at position 2 and either $\mathrm{A}, \mathrm{I}, \mathrm{L}, \mathrm{M}, \mathrm{V}, \mathrm{F}, \mathrm{W}$, or $\mathrm{Y}$ at the $\mathrm{COOH}$ terminus.

Highly conserved HBV peptides that bind with high affinity to several members of a given supertype have the potential of being degenerate immunogens. Degenerate immunogenicity is defined as the capacity of a given peptide to be immunogenic in the context of multiple HLA molecules and has been clearly demonstrated for HLA class II DR molecules (30-37) but until now only rarely $(38,39)$ in the case of class I molecules.

In this study, we analyzed the class I restricted CTL response of acutely infected patients to three panels of highly conserved HBV peptides that bind with high affinity to multiple alleles of either the A2-, A3-, or B7-supertypes. Several new epitopes were identified by this strategy, and a number of cross-reactive peptides were identified that are recognized as CTL epitopes in the context of multiple alleles within their corresponding supertypes. Two nested epitope sets were also recognized by class I alleles with completely unrelated peptide specificities. Demonstration of the degenerate immunogenicity for class I binding peptides in a natural disease setting such 
as HBV validates the concept of class I HLA supertypes at the biological level. In addition, identification of degenerate CTL epitopes will facilitate analysis of the immunobiology and pathogenesis of hepatitis B infection. Finally, these results provide a rational basis for the development of a broadly reactive, ethnically diverse, synthetic peptide vaccine (40) for the treatment of patients with chronic HBV infection, whose CTL response to HBV is innately weak and ineffective (4).

\section{Methods}

Patient population. The PBMC from a total of 240 individuals (145 chronic and 95 acute hepatitis patients) were HLA typed (Table I) and considered for inclusion in this study. A representative subset of patients was analyzed in more detail (Table II). Specifically, 67 patients with acute hepatitis $\mathrm{B}$, and 12 patients who had recently recovered from acute hepatitis B, were studied. 37 of these patients expressed one or more HLA alleles that are members of the A2supertype, 35 patients expressed A3-supertype alleles, and 14 patients expressed B7-supertype alleles. Finally, 13 patients who were positive for expression of the HLA-A1 antigen were also analyzed. Due to the expression of two or more of the supertype alleles, and/or HLA-A1, in some of the patients, the total number of observations ( $n=$ $99)$ is greater than the number of patients studied $(n=79)$. The diagnosis of acute hepatitis B was based on clinical and biochemical evidence of acute liver injury, according to standard diagnostic criteria, including serum alanine amino transferase activity at least 10 -fold greater than the upper normal limit, together with serological evidence of acute HBV infection, including hepatitis B surface antigen (HBsAg) and IgM anti-HBc antibody (IgM HBc-Ab) and the absence of serologic evidence of hepatitis $\delta$ and hepatitis $\mathrm{C}$ virus (Abbott Laboratories, North Chicago, IL). All patients recovered completely from illness with normalization of serum transaminase and clearance of HBsAg within two months of initial diagnosis. All patients were serologically negative for antibody to HIV. These studies were approved by the Institutional Human Subjects Committee of The Scripps Research Institute.

Synthetic peptides, HBV antigens. Three panels of highly conserved HBV peptides (9-11 mers) that bind multiple HLA alleles with high affinity (Table III) were either synthesized at Cytel Corporation (San Diego, CA) as previously described (6) or purchased from Chiron Mimotopes (Clayton, Victoria, Australia). Peptides synthesized at Cytel were purified to $>95 \%$ homogeneity by reverse-phase HPLC, and their composition was ascertained by amino acid analysis, sequencing, and/or mass spectrometric analysis. Peptide aliquots used in binding assays were diluted at either 4 or $12 \mathrm{mg} / \mathrm{ml}$ in $100 \%$ DMSO. Subsequent dilutions were done in PBS with $0.05 \%$ NP40. Otherwise, lyophilized peptides were reconstituted at $20 \mathrm{mg} / \mathrm{ml}$ in DMSO (Mallinckrodt Inc., Paris, KY) and diluted to $1 \mathrm{mg} / \mathrm{ml}$ with RPMI-1640 medium (GIBCO Laboratories, Grand Island, NY). Recombinant $\mathrm{HBcAg}$ was obtained from bacterial extracts of Escherichia coli as previously described (41).

HLA-binding affinity assays. Binding affinity of peptides to purified detergent solubilized class I MHC molecules was quantitated as previously described (42) by measuring the inhibition of binding of a radiolabeled standard probe peptide. In brief, purified class I molecules were incubated for $2 \mathrm{~d}$ at room temperature with 5-10 nM of the labeled peptide, $1 \mu \mathrm{M}$ of human $\beta 2$-microglobulin (Scripps Laboratories, San Diego, CA), and a cocktail of protease inhibitors. After incubation, class I peptide complexes were separated from free peptide by size exclusion gel filtration chromatography on a TSK2000 column $(7.8 \mathrm{~mm} \times 15 \mathrm{~cm}$; TosoHaas, Montgomeryville, PA). Concentrations of MHC yielding $\sim 15 \%$ binding of the radiolabeled probe peptide were used in subsequent competitive inhibition assays. In competitive binding assays the concentration of peptide yielding $50 \%$ inhibition of the binding of the radiolabeled probe peptide was calculated.
Specifics for the A3-supertype and B7-supertype assays have been described in detail elsewhere (references 27 and 28, respectively). For the A2-supertype assays the following EBV transformed cell lines were used as sources of class I molecules: JY (A*0201), FUN (A*0203/A3), CLA (A*0206/A24), and AMAI (A*6802). The mouse mastocytoma P815 transfected with $A * 0202$ was also utilized. Cell lines were maintained, lysates prepared, and class I molecules purified, as previously described (42). A $F_{6}$ to $Y$ analogue of the HBV core 18-27 peptide (sequence FLPSDYFPSV) (6) was used as the radiolabeled probe for the $A * 0201, A * 0202, A * 0203$, and A*0206 assays. $\mathrm{A} \mathrm{C}_{4}$ to $\mathrm{A}$ analogue of the HBV Pol 646-654 peptide (sequence FTQAGYPAL) was used as the radiolabeled probe for the $A * 6802$ assay. The average $\mathrm{IC}_{50}$ of the $\mathrm{HBV}$ core $18-27 \mathrm{~F}_{6}$ to $\mathrm{Y}$ analogue peptide for the $\mathrm{A} * 0201, \mathrm{~A} * 0202, \mathrm{~A} * 0203$, and $\mathrm{A} * 0206$ assays were 5, 4.3, 10 , and $3.7 \mathrm{nM}$, respectively. The average $\mathrm{IC}_{50}$ of the $\mathrm{C}_{4}$ to $\mathrm{A}$ analogue of the HBV Pol 646-654 $\mathrm{C}_{4}$ to $\mathrm{A}$ analogue peptide in the A*6802 assay was $40 \mathrm{nM}$.

Stimulation of PBMC with synthetic peptides and $r H B c A g$. PBMC from patients with acute HBV infection were separated on FicollHistopaque density gradients (Sigma Chemical Co., St. Louis, MO) washed three times in HBSS (GIBCO Laboratories) resuspended in RPMI-1640 (GIBCO Laboratories) supplemented with L-glutamine $(2 \mathrm{mM})$, penicillin $(50 \mathrm{U} / \mathrm{ml})$, streptomycin $(50 \mu \mathrm{g} / \mathrm{ml})$, and Hepes $(10$ $\mathrm{mM}$ ) containing $10 \%$ heat-inactivated human $\mathrm{AB}$ serum (complete RPMI) and plated using bulk culture and microculture formats that we have previously described $(1,12)$. In both of the methods used, synthetic peptides were added at $10 \mu \mathrm{g} / \mathrm{ml}$ to each well and $\mathrm{rHBcAg}$ was added at $1 \mu \mathrm{g} / \mathrm{ml}$ to each well as a source of T cell help during the first week of stimulation.

In the bulk culture format, $4 \times 10^{6} \mathrm{PBMC}$ were stimulated with peptide in a single well of a 24-well plate in $1 \mathrm{ml}$ of complete RPMI. On day 3 and 10, $1 \mathrm{ml}$ of RPMI with 10\% (vol/vol) of human AB serum and rIL-2 (Hoffmann-La Roche, Inc., Nutley, NJ) at $20 \mathrm{U} / \mathrm{ml}$ final concentration was added to each well. On day 7 , the cultures were restimulated with peptide, rIL-2 and $10^{6}$ irradiated (3,000 rad) autologous feeder cells. The cultures were tested for cytotoxic activity on day 14. Duplicate assays yielding greater than $15 \%$ specific ${ }^{51} \mathrm{Cr}$ release were considered positive based on comparison with uninfected control subjects, as previously described $(1-3,8,13,43,44)$.

In the microculture format, $4 \times 10^{5} \mathrm{PBMC}$ were stimulated with peptide in 8 replicate cultures in 96-well round-bottom plate in 100 $\mathrm{ml} /$ well of complete RPMI. On days 3 and 10, $100 \mathrm{ml}$ of complete RPMI and $20 \mathrm{U} / \mathrm{ml}$ final concentration of rIL-2 were added to each well. On day 7 the cultures were transferred into a 96-well flat-bottom plate and restimulated with peptide, rIL-2 and $10^{5}$ irradiated $(3,000$ rad) autologous feeder cells. The cultures were tested for cytotoxic activity on day 14 . A positive CTL response required two or more of the eight replicate cultures to display greater than $10 \%$ specific ${ }^{51} \mathrm{Cr}$ release, based on comparison with uninfected control subjects as previously described $(11,12,15)$.

Target cell lines. Autologous and allogeneic EBV-transformed B-LCL were either purchased from the American Society for Histocompatibility and Immunogenetics (ASHI, Boston, MA) or established from our own pool of patients as described (43). All target cells were maintained in RPMI with $10 \%$ (vol/vol) heat-inactivated FCS (GIBCO Laboratories).

Cytotoxicity assay. Target cells consisted of either allogeneic HLA-matched or autologous EBV-transformed B lymphoblastoid cell line that were incubated overnight with synthetic peptides at $10 \mu \mathrm{M}$ and labeled with $100 \mu \mathrm{Ci}$ of ${ }^{51} \mathrm{Cr}$ (Amersham Corp., Arlington Heights, IL) for $1 \mathrm{~h}$ after which they were washed four times with HBSS. Cytolytic activity was determined in a standard 4-h split-well ${ }^{51} \mathrm{Cr}$ release assay using U-bottomed 96 well plates containing either 5,000 targets/ well for the bulk culture or 3,000 targets/well for the microculture formats. Stimulated PBMC were tested at E/T ratios of 20-50:1 on day 14. Percent cytotoxicity was determined from the formula: $100 \times[(\mathrm{ex}-$ perimental release-spontaneous release)/(maximum release-spontaneous release)]. Maximum release was determined by lysis of targets 
by detergent ( $2 \%$ Triton X-100; Sigma Chemical Co.). Spontaneous release was $<25 \%$ of maximum release in all experiments.

HLA typing. HLA typing of PBMC from patients was determined by complement microcytotoxicity, using HLA typing trays (One Lambda, Canoga Park, CA). HLA-A2 subtyping was performed using a PCR subtyping procedure based on the pattern of PCR amplification with allele specific amplimers $(45,46)$. In this procedure, a set of six PCR reactions identify 13 diagnostic codons that differentiate A2.1 from most prevalent HLA-A2 subtypes (47).

\section{Results}

Selection of HBV-derived A2-supertype potential CTL epitopes. To select appropriate A2-supertype-restricted CTL epitopes, we first scanned the sequence of the HBV Polymerase (Pol), Nucleocapsid (Core), and Envelope (Env) antigens for the presence of peptide epitopes conserved among at least $85 \%$ of 20 full length HBV genomes, in the GenBank Database, and containing A*0201 extended motifs (7). Ninety-nine 9- and 10mer peptides (potential epitopes) were synthesized and tested for their $\mathrm{A}^{*} 0201$ binding capacity. A total of $11 \operatorname{good}\left(\mathrm{IC}_{50} \%\right.$ $\leq 50 \mathrm{nM})$ and 13 intermediate $\left(\mathrm{IC}_{50} \%\right.$ in the $50-500 \mathrm{nM}$ range) binding peptides were identified (data not shown). It has previously been shown that the majority of known CTL epitopes, naturally processed HLA-binding peptides, peptides recognized by patients with acute hepatitis and peptides that are immunogenic in $A^{*} 0201 / \mathrm{K}^{\mathrm{b}}$ transgenic animals display HLA class I affinities of $500 \mathrm{nM}$ or less $(9,10)$. Accordingly, the 24 A*0201 HBV peptides binding with $\mathrm{IC}_{50} \%$ of $500 \mathrm{nM}$ or less were tested for immunogenicity in $A * 0201 / K^{b}$ transgenic mice (10), and primary CTL responses in vitro (43). Overall, 5/11 of the high binders and 1/13 of the intermediate binders tested, were found to be consistently immunogenic in both assay systems $(9,10)$ (data not shown). These six A*0201 restricted HBV epitopes were selected for further experiments.

In addition, the Env 183 and Pol 455 peptides were also selected for further experiments. The Env 183 peptide was included because of its good $A^{*} 0201$ binding capacity and its recognition by $A^{*} 0201$ positive patients with acute hepatitis (11). Furthermore, in the case of Env 183 the presence of a class II restricted epitope overlapping with the class I epitope has also been demonstrated (48).

These eight peptides were tested for their capacity to bind other prevalent members of the A2-supertype $(25,29)$. The additional alleles considered were $A * 0202$ and $A * 6802$, which are prevalent in blacks (6.7 and $11.9 \%$, respectively), but also $A^{*} 0203$ and $A * 0206$, which are prevalent in Chinese (5.4 and $14.7 \%$, respectively).

It was found that most peptides exhibited cross-reactive behavior (Table III). More specifically, the Core 18-27 peptide bound five out of five alleles tested with affinities of $500 \mathrm{nM}$ or lower. Env 335, Env 183, and Pol 642 bound four out of five alleles, Pol 455 bound three and Env 62 and Pol 575, bound two of the five A2-supertype alleles tested with affinities of $500 \mathrm{nM}$ or less. In summary, these experiments identified a set of six A*0201 epitopes capable of binding in vitro to multiple A2supertype molecules. A total of 5/8 (63\%) of the A*0201 epitopes tested bound at least three out of the five common A2supertype molecules tested.

Selection of $H B V$ derived, potential A3- and B7-supertype epitopes. Next, we examined the same HBV sequences from the 20 different HBV isolates used above for the presence of conserved peptides carrying the A3-supermotif (27). This motif selects peptides bearing A, V, I, L, M, S, or T in position 2, and $\mathrm{R}$ or $\mathrm{K}$ at the $\mathrm{COOH}$ terminus. Thirty-seven 9- or 10 -mer sequences containing the A3-supermotif were identified, and the corresponding peptides were synthesized. Because of the high prevalence of HLA-A3 in most major population groups, 11 peptides containing $\mathrm{Y}$ at their $\mathrm{COOH}$ terminus, which is tolerated by A3 molecules, were also synthesized. Finally, four 11-mer peptides were synthesized, one of which (Core 141) was previously reported to be restricted by two A3-supertype alleles (3), and three others (Pol 149, Pol 357, and Pol 735) which represent extensions of 10 -mer peptides that also carry the A3 supermotif.

All of these peptides were tested for binding to A3 and A11, the two most prevalent A3-supertype alleles. 20 different peptides were identified which bound A3 and/or A11 (Table III) with affinities of $500 \mathrm{nM}$ or less. These potential epitopes were subsequently tested for binding cross-reactivity among other common members of the A3-supertype (A*3101, A*3301, and $A * 6801) .6$ of these 20 peptides $(30 \%)$ bound at least three out of the five A3-supertype alleles tested; 13 peptides $(65 \%)$ bound at least two of the alleles tested (Table III).

Next, we sought to define conserved potential B7-supertype HBV epitopes for use in our study. In this case, the B7supermotif (26), which identifies peptides bearing $\mathrm{P}$ in position 2 and V, I, L, M, W, F, Y, or A at the COOH terminus of 9- or 10 -mer peptides, was used. A total of 30 candidates all corresponding to highly conserved HBV sequences were synthesized. As was the case for the A2- and A3-supertypes, the B7-supertype peptides were first screened for binding to a prevalent supertype molecule. In this case, all 30 peptides were tested for binding to HLA B*0702. Seven peptides bound $\mathrm{B} * 0702$ with $\mathrm{IC}_{50} \mathrm{nM} \leq 500$ (Table III). These peptides were subsequently screened for binding to other prevalent B7supertype molecules (B*3501, B51, B*5301, and B*5401). We also included in this secondary screening the B7-supermotif bearing HBV Core 19-27 peptide, which represents a truncation of the HBV Core 18-27 A*0201 epitope.

It was found that 6 peptides, including the HBV Core 19-27 peptide, were capable of binding multiple B7-supertype alleles. More specifically, one peptide, Pol 530, bound to all five B7-supertype alleles, four different peptides bound four B7supertype alleles, and one peptide bound two of the five B7supertype alleles tested. In summary, these studies identified a total of 20 peptides, all derived from conserved regions of the HBV genome, and capable of binding to multiple A3- or B7supertype HLA class I molecules. It can also be noted that $6 / 20$ (30\%) A3-supertype peptides, and 5/7 (71\%) of the B7-supertype peptides, bound at least three out of the five alleles tested of the appropriate supertype.

HLA supertype peptide-specific CTL response patterns. In the next series of experiments, the HLA Class I type of patients who were either acutely or chronically HBV infected was examined (Table I). Overall, close to $45 \%$ of them (38 to $50 \%$ for acute, and 38 to $58 \%$ for chronic patients) were positive for expression of either the B7-, A2-, or the A3-supertypes. Furthermore, 126 out of $145(86.9 \%)$ and 88 out of 95 $(92.6 \%)$ of acute and chronic patients, respectively, were positive for at least one of the three supertypes (because some patients express antigens of more than one supertype, the percentages in Table I do not add up to $100 \%$ ).

A representative subset of patients positive for each of the 
Table I. Frequency of HLA Supertypes in Acute and Chronic Hepatitis Patients

\begin{tabular}{|c|c|c|c|c|c|}
\hline \multirow[b]{3}{*}{ Supertype } & \multirow[b]{3}{*}{ Antigen } & \multicolumn{4}{|c|}{ Hepatitis B patients } \\
\hline & & \multicolumn{2}{|c|}{ Acute } & \multicolumn{2}{|c|}{ Chronic } \\
\hline & & $n$ & $\%$ & $n$ & $\%$ \\
\hline \multirow[t]{4}{*}{ A2 } & A2 & 71 & $(49.0)$ & 54 & $(56.8)$ \\
\hline & $A * 6802$ & 2 & (1.4) & 0 & $(0.0)$ \\
\hline & $A * 6901$ & 2 & (1.4) & 2 & (2.1) \\
\hline & Total & 73 & $(50.3)$ & 55 & $(57.9)$ \\
\hline \multirow[t]{9}{*}{ A3 } & A3 & 23 & (15.9) & 11 & (11.6) \\
\hline & A11 & 8 & (5.5) & 14 & $(14.7)$ \\
\hline & A31 & 11 & (7.6) & 4 & $(4.2)$ \\
\hline & A33 & 11 & (7.6) & 6 & (6.3) \\
\hline & A34 & 1 & $(0.7)$ & 4 & $(4.2)$ \\
\hline & A66 & 1 & $(0.7)$ & 1 & (1.1) \\
\hline & $A * 6801$ & 6 & (4.1) & 0 & $(0.0)$ \\
\hline & A74 & 1 & $(0.7)$ & 1 & (1.1) \\
\hline & Total & 55 & $(37.9)$ & 39 & (41.1) \\
\hline \multirow[t]{10}{*}{ B7 } & B7 & 12 & (8.3) & 15 & (15.8) \\
\hline & B35 & 29 & $(20.0)$ & 10 & (10.5) \\
\hline & B51 & 12 & (8.3) & 6 & $(6.3)$ \\
\hline & B53 & 7 & $(4.8)$ & 2 & (2.1) \\
\hline & B54 & 1 & $(0.7)$ & 1 & (1.1) \\
\hline & B55 & 0 & $(0.0)$ & 3 & (3.2) \\
\hline & B56 & 2 & (1.4) & 2 & (2.1) \\
\hline & B67 & 5 & (3.4) & 4 & $(4.2)$ \\
\hline & B78 & 0 & $(0.0)$ & 0 & $(0.0)$ \\
\hline & Total & 65 & $(44.8)$ & 36 & (37.9) \\
\hline $\mathrm{A} 2, \mathrm{~A} 3$, or $\mathrm{B} 7 *$ & & 126 & $(86.9)$ & 88 & (92.6) \\
\hline Total & & 145 & (100.0) & 95 & (100.0) \\
\hline
\end{tabular}

* Sum includes 10 acute and 5 chronic hepatitis patients that are A68 positive but have not been subtyped.

three supertypes (Table II) was next tested for anti-HBV CTL reactivity. Included in the subset were patients who were either acutely infected, or recently convalescent from acute HBV infection. The latter group was included because it was previously reported that the CTL response to HBV persists for several decades after recovery from acute hepatitis (11). In our studies, we tested sets of HBV derived A2-, A3-, and B7supertype peptides for their capacity to induce recall CTL responses in patients expressing HLA antigens from appropriate matching supertypes, as predicted on the basis of their HLA class I binding capacity. In the case of the A2-supertype, all of the A*0201 epitopes listed in Table III were included, except Env 62 and Pol 538, which were not tested because they were poorly cross-reactive among other A2-supertype alleles (Table III). In the case of the A3-supertype peptides, we studied all of the peptides binding three or more of the five A3-supertype alleles plus two peptides ( Pol 55 and Pol 150) that bound two out of the five A3-supertype alleles tested (Table III). Finally, in the HLA-B7-supertype study, we included all peptides known to bind two or more of the five B7-supertype alleles tested (Table III).

Peptide specific CTL responses were established by stimulation of PBMC with peptide and r-IL2 in bulk culture and mi-
Table II. Patient Subset Whose Anti-HBV CTL Responses Were Studied

\begin{tabular}{lccccc}
\hline & \multicolumn{4}{c}{ HBV-infected patients } \\
\cline { 2 - 3 } \multicolumn{1}{c}{ Group } & $n$ & & \multicolumn{2}{c}{ CTL responders } \\
\cline { 2 - 5 } \cline { 5 - 6 } Total & $\%$ & $n$ & $\%$ \\
\hline \multirow{2}{*}{ Males } & 59 & $(74.7)$ & 33 & $(55.9)$ \\
Females & 20 & $(25.3)$ & 12 & $(60.0)$ \\
Total & 79 & $(100.0)$ & 45 & $(57.0)$ \\
A2 supertype & 37 & $(46.8)$ & 28 & $(75.7)$ \\
A3 supertype & 35 & $(44.3)$ & 16 & $(45.7)$ \\
B7 supertype & 14 & $(17.7)$ & 2 & $(14.3)$ \\
A1 antigen & 13 & $(16.5)$ & 3 & $(23.1)$ \\
Total & $99 *$ & & 49 & $(49.5)$ \\
& & & & \\
\hline
\end{tabular}

*20 patients are included in two or more supertypes.

croculture formats, which have been shown to be of comparable sensitivity (15). Fig. 1 (top) shows representative results of bulk culture and microculture stimulations for patient 1 (HLA A*0201, B51, B53), displaying his CTL response to the A2and B7-supertype peptides, using target cells matched only at HLA-A*0201 and HLA-B51, respectively. It is evident that this patient produced a polyclonal, multispecific CTL response to all of the A2-supertype peptides and to 3 of the 6 B7-supertype peptides in an HLA-restricted manner.

Additional results of the microculture format are also shown for patient 2 (HLA A*0201, A11, B35, B51) in Fig. 1 (bottom), displaying his CTL response to peptides from all three supertypes. These results indicate that this patient responded to four of six A2-supertype peptides, to six of the eight A3-supertype peptides and to two of the six B7-supertype peptides. Furthermore, using HLA-matched and mismatched allogeneic target cells, the CTL responses in this patient were shown to be restricted by HLA-A*0201, -A11 and -B51 (not shown).

Overall, we observed an HLA allele-specific hierarchy of CTL responsiveness to this panel of peptides. As shown in Table II, a CTL response to one or more of the A2-supertype peptides was observed in 28 out of 37 patients (76\%). In contrast, 46 and $14 \%$ of patients from the A3- and B7-supertypes, respectively, responded to the corresponding peptides. The higher antigenicity of A2-supertype peptides in acute hepatitis patients is likely to be at least in part reflective of the fact that the A2-supertype peptides were prescreened for immunogenicity in many other acutely infected patients $(1,2,8)$ normal $\mathrm{A} 2+$ donors, and HLA transgenic mice.

HLA degenerate immunogenicity of supertype peptides. A summary of the supertype-peptide-specific CTL responses in 70 patients who expressed one or more of the A2-, A3-, and B7-supertype alleles is shown in Table IV. The results in this table indicate the number of patients who responded to each peptide (numerator) relative to the number of patients who were tested with the corresponding peptide (denominator). Because of the differential prevalence of HLA alleles in our patient population, certain alleles were more highly represented than others. Therefore negative results obviously do not necessarily indicate that a given peptide is not recognized in the context of a particular allele, especially if it was only studied in one or two patients. 


\begin{tabular}{|c|c|c|c|c|c|c|c|c|c|c|}
\hline \multirow[b]{2}{*}{ Peptide } & \multirow[b]{2}{*}{ Protein } & \multirow[b]{2}{*}{ Position } & \multirow[b]{2}{*}{ Frequency* } & \multicolumn{5}{|c|}{ Binding $\left(\mathrm{IC}_{50} \mathrm{nM}\right)$} & \multirow{2}{*}{$\begin{array}{c}\text { Alleles } \\
\text { bound }\end{array}$} & \multirow{2}{*}{$\begin{array}{c}\text { CTL } \\
\text { analysi }\end{array}$} \\
\hline & & & & $\mathrm{A}^{* 0201}$ & $A * 0202$ & A*0203 & A*0206 & $A * 6802$ & & \\
\hline FLPSDFFPSV & CORE & 18 & $85^{\ddagger}$ & $2.5^{\S}$ & 2.0 & 5.9 & 2.8 & 36 & 5 & $\mathrm{Y}^{\|}$ \\
\hline FLLTRILTI & ENV & 183 & $80^{\frac{1}{+}}$ & 9.8 & 100 & 1.0 & 38 & - I & 4 & $\mathrm{Y}$ \\
\hline WLSLLVPFV & ENV & 335 & 100 & 4.5 & 113 & 1.4 & 10 & 1290 & 4 & $\mathrm{Y}$ \\
\hline ALMPLYACI & POL & 642 & 95 & 10 & 126 & 3.0 & 148 & 851 & 4 & $\mathrm{Y}$ \\
\hline GLSRYVARL & POL & 455 & $90^{\ddagger}$ & 79 & 391 & 18 & 12333 & - & 3 & $\mathrm{Y}$ \\
\hline FLLSLGIHL & POL & 575 & 95 & 7.7 & 4300 & 1000 & 34 & 11429 & 2 & $\mathrm{Y}$ \\
\hline GLLGWSPQA & ENV & 62 & 85 & 13 & 14333 & 286 & 1321 & - & 2 & $\mathrm{~N}$ \\
\hline YMDDVVLGA & POL & 538 & 90 & 200 & - & 4167 & - & - & 1 & $\mathrm{~N}$ \\
\hline
\end{tabular}

B A3 supertype

\begin{tabular}{|c|c|c|c|c|c|c|c|c|c|c|}
\hline \multirow[b]{2}{*}{ Peptide } & \multirow[b]{2}{*}{ Protein } & \multirow[b]{2}{*}{ Position } & \multirow[b]{2}{*}{ Frequency } & \multicolumn{5}{|c|}{ Binding $\left(\mathrm{IC}_{50} \mathrm{nM}\right)$} & \multirow{2}{*}{$\begin{array}{l}\text { Alleles } \\
\text { bound }\end{array}$} & \multirow{2}{*}{$\begin{array}{c}\text { CTL } \\
\text { analysis }\end{array}$} \\
\hline & & & & $\mathrm{A} 3$ & A11 & $A * 3101$ & $A * 3301$ & $A * 6801$ & & \\
\hline HTLWKAGILYK & POL & 149 & 100 & 20 & 14 & 486 & 403 & 42 & 5 & $\mathrm{Y}$ \\
\hline STLPETTVVRR & CORE & 141 & 100 & 733 & 4 & 181 & 181 & 26 & 4 & $\mathrm{Y}$ \\
\hline NVSIPWTHK & POL & 47 & 10 & 134 & 105 & - & 2900 & 250 & 3 & $\mathrm{Y}$ \\
\hline QAFTFSPTYK & POL & 654 & 95 & 244 & 11 & 18000 & 5088 & 6.7 & 3 & $\mathrm{Y}$ \\
\hline SAICSVVRR & POL & 520 & 95 & 1897 & 29 & 1200 & 446 & 21 & 3 & $\mathrm{Y}$ \\
\hline LVVDFSQFSR & POL & 377 & 100 & 6875 & 17 & 602 & 126 & 16 & 3 & $\mathrm{Y}$ \\
\hline KVGNFTGLY & POL & 55 & 95 & 37 & 429 & - & - & - & 2 & $\mathrm{Y}$ \\
\hline TLWKAGILYK & POL & 150 & 100 & 2 & 17 & 3529 & - & 615 & 2 & $\mathrm{Y}$ \\
\hline VTGGVFLVDK & POL & 358 & 100 & 282 & 65 & - & - & 3636 & 2 & $\mathrm{~N}$ \\
\hline VVDFSQFSR & POL & 378 & 100 & 7333 & 80 & 13846 & 1706 & 242 & 2 & $\mathrm{~N}$ \\
\hline STLPETTVVR & NUC & 170 & 85 & 15714 & 100 & 2250 & 1208 & 320 & 2 & $\mathrm{~N}$ \\
\hline TLPETTVVRR & NUC & 171 & 85 & 15714 & 261 & - & 2417 & 182 & 2 & $\mathrm{~N}$ \\
\hline PVNRPIDWK & POL & 612 & 85 & 355 & 43 & - & - & 8889 & 2 & $\mathrm{~N}$ \\
\hline HTLWKAGILY & POL & 149 & 100 & 250 & 7500 & - & 8529 & 6667 & 1 & $\mathrm{~N}$ \\
\hline GTDNSVVLSR & POL & 735 & 90 & 10000 & 107 & 20000 & - & 20000 & 1 & $\mathrm{~N}$ \\
\hline YMDDVVLGAK & POL & 538 & 90 & 333 & 1395 & - & - & - & 1 & $\mathrm{~N}$ \\
\hline TLWKAGILY & POL & 150 & 100 & 85 & 7500 & - & - & - & 1 & $\mathrm{~N}$ \\
\hline GTDNSVVLSRK & POL & 735 & 90 & 786 & 11 & - & - & - & 1 & $\mathrm{~N}$ \\
\hline RVTGGVFLVDK & POL & 357 & 100 & 579 & 207 & - & - & - & 1 & $\mathrm{~N}$ \\
\hline MMWYWGPSLY & ENV & 360 & 85 & 220 & 7500 & - & - & - & 1 & $\mathrm{~N}$ \\
\hline
\end{tabular}

C B7 supertype

\begin{tabular}{|c|c|c|c|c|c|c|c|c|c|c|}
\hline \multirow[b]{2}{*}{ Peptide } & \multirow[b]{2}{*}{ Protein } & \multirow[b]{2}{*}{ Position } & \multirow[b]{2}{*}{ Frequency } & \multicolumn{5}{|c|}{ Binding $\left(\mathrm{IC}_{50} \mathrm{nM}\right)$} & \multirow{2}{*}{$\begin{array}{l}\text { Alleles } \\
\text { bound }\end{array}$} & \multirow{2}{*}{$\begin{array}{c}\text { CTL } \\
\text { analysis }\end{array}$} \\
\hline & & & & $\mathrm{B} * 0702$ & $B * 3501$ & B51 & $B * 5301$ & $B * 5401$ & & \\
\hline FPHCLAFSYM & POL & 530 & 95 & 56 & 33 & 61 & 118 & 208 & 5 & $\mathrm{Y}$ \\
\hline LPSDFFPSV & CORE & 19 & 85 & 1774 & 171 & 9 & 120 & 4.8 & 4 & $\mathrm{Y}$ \\
\hline IPIPSSWAF & ENV & 313 & 100 & 29 & 2.6 & 220 & 7.2 & 833 & 4 & $\mathrm{Y}$ \\
\hline HPAAMPHLL & POL & 429 & 100 & 56 & 267 & 500 & 186 & 833 & 4 & $\mathrm{Y}$ \\
\hline YPALMPLYA & POL & 640 & 95 & 306 & 150 & 162 & 664 & 0.63 & 4 & $\mathrm{Y}$ \\
\hline TPARVTGGVF & POL & 354 & 90 & 17 & 72 & - & 939 & 16667 & 2 & $\mathrm{Y}$ \\
\hline HPAAMPHLLV & POL & 429 & 85 & 344 & 3600 & 705 & 664 & 588 & I & $\mathrm{N}$ \\
\hline DPSRGRLGL & POL & 778 & 90 & 458 & - & - & - & - & 1 & $\mathrm{~N}$ \\
\hline
\end{tabular}

* Frequency $(\%)$ of peptide sequence among HBV isolates reported in the GenBank database. ${ }^{\ddagger}$ Cumulative frequency including variants cross-reactive at the T cell level (see reference 6; and Chisari, F., and A. Sette, unpublished observations). ${ }^{\S}$ Binding affinities up to $500 \mathrm{nM}$ are shown in bold. ${ }^{\pi} \mathrm{A}$ dash indicates $\mathrm{IC}_{50} \mathrm{nM} \geq 25,000$. $\|$ Peptide specific CTL assays performed $(\mathrm{Y})$ or not performed $(\mathrm{N})$. 


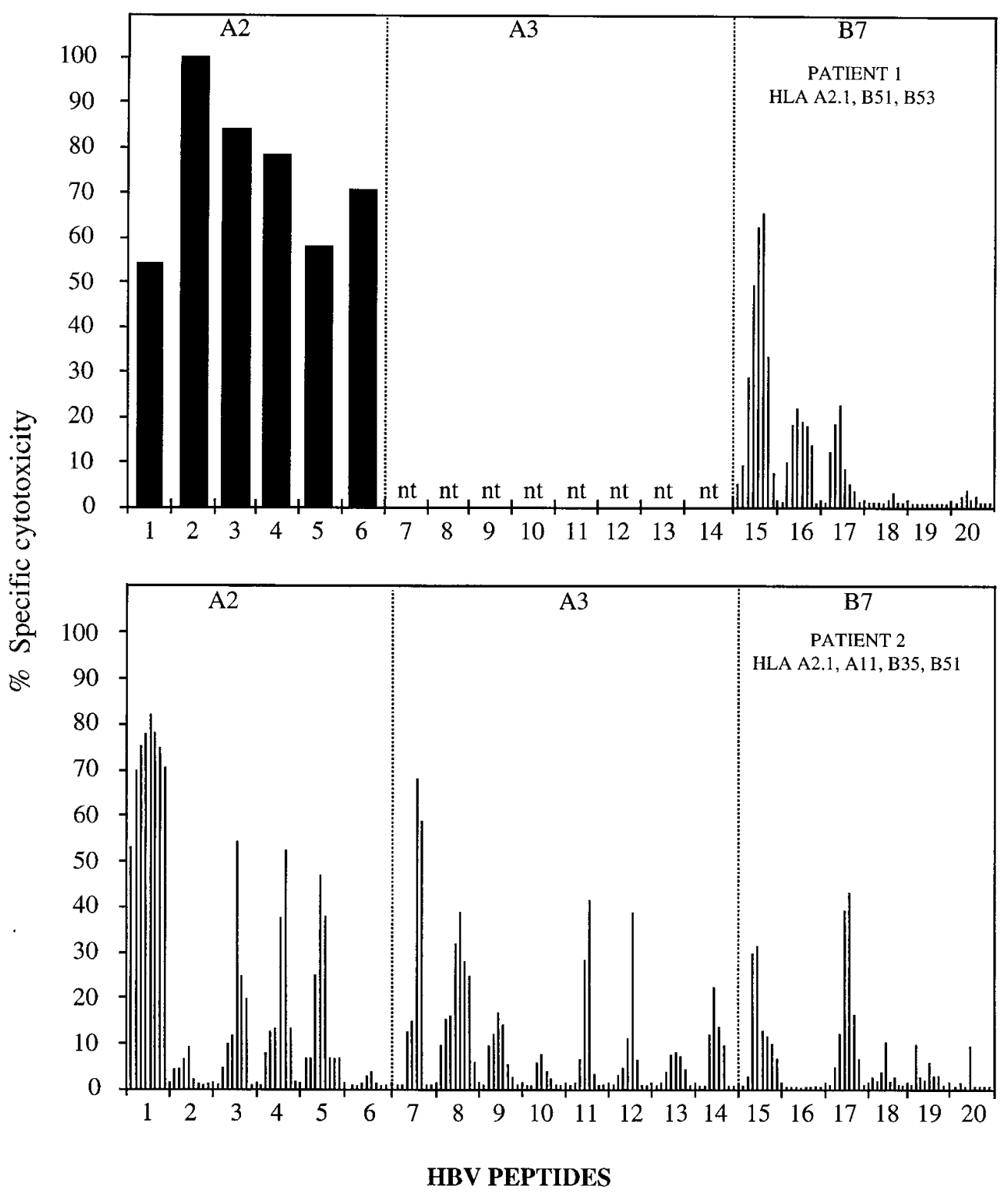

Figure 1. HBV specific CTL responses in two patients with acute hepatitis B. PBMCs were stimulated with $10 \mu \mathrm{g}$ of peptide/ $\mathrm{ml}$ using either the bulk culture protocol (patient 1, peptides 1-6) or the microculture protocol (all the other responses) as described in Methods. The HBV peptides 1-20 are in the same order as presented in Table IV. A $4-\mathrm{h}^{51} \mathrm{Cr}$ release assay was performed on day 14 at an E/T cell ratio of 2050:1 using target cells prepulsed overnight with the same peptide and matched only at the HLAalleles indicated at the top of each data set. Cut-off values of $\geq 15 \%$ specific lysis were considered positive responses in the bulk culture format, while two or more wells displaying $\geq 10 \%$ specific lysis defined a positive response in the microculture assay.
It was found that $17 / 20$ peptides were capable of eliciting positive CTL responses (Table IV), indicating that most of the degenerate binders are generated by processing of HBV antigens in the course of viral infection (Table IV). Most importantly, however, Table IV also illustrates that 9 of the 20 peptides (four out of six A2-supertype, and five out of eight A3-supertype peptides) are degenerate, being recognized in the context of multiple supertype alleles. These results suggest that degenerate HLA binding is likely to be predictive of degenerate immunogenicity.

It is evident that certain peptides are more frequently recognized than others within each supertype. As indicated above, the data also reveal an immune response hierarchy in which the A2-supertype dominates, the A3-supertype is intermediate and the B7-supertype is least responsive.

Recognition of nested HBV epitopes by HLA class I types of unrelated specificities. The results described above demonstrate how the same peptide epitope can be recognized in the context of multiple HLA molecules sharing similar peptide specificities, and which thereby belong to the same HLA supertype. It should be noted, however, that recognition of the same peptide region in the context of completely unrelated class I molecules could also occur if the corresponding binding motifs are nested within the same peptide region (49).

An example of this occurrence is provided by the highly conserved Pol 149-159 region. The peptide Pol 149-159 was recognized by an A3 patient, and Pol 150-159 was recognized by patients in the context of both HLA-A3 and HLA-A11. This region also contains a peptide (Pol 149-158), which carries a canonical HLA-A*0101 motif [T, S in position 2 or D, E in position 3, and a $\mathrm{Y}$ at the peptide $\mathrm{COOH}$ termini; (7)], and which accordingly binds HLA-A*0101 with good affinity $(381 \mathrm{nM})$. Pol 150-158, also contained within this region, has an imperfect A*0101 motif, and binds $A * 0101$ with relatively poor affinity (24,700 nM). Pol 149-159 and Pol 150-159, which carry COOHterminal $\mathrm{K}$, and thereby do not possess A*0101 motifs, do not bind $A * 0101$, as expected (not shown). We reasoned that, if limited in vitro processing would allow removal of the $\mathrm{COOH}$ 
A A2 supertype peptides

\begin{tabular}{|c|c|c|c|c|c|c|c|}
\hline \multirow[b]{2}{*}{ Peptide } & \multirow[b]{2}{*}{ Protein } & \multirow[b]{2}{*}{ Position } & \multicolumn{5}{|c|}{ CTL responsiveness (No. Pos/No. Tested) } \\
\hline & & & $A * 0201$ & A*0202 & $\mathrm{A} * 0205 / 6$ & $A * 6802$ & All \\
\hline 1. FLPSDFFPSV & CORE & 18 & $22 / 25$ & $0 / 1$ & $3 / 6$ & $n \mathrm{t}^{\dot{亠}}$ & $25 / 32$ \\
\hline 2. FLLTRILTI & ENV & 183 & $12 / 18$ & $0 / 1$ & $2 / 4$ & $\mathrm{nt}$ & $14 / 23$ \\
\hline 3. WLSLLVPFV & ENV & 335 & $19 / 23$ & 1/1 & $3 / 5$ & $\mathrm{nt}$ & 23/29 \\
\hline 4. GLSRYVARL & POL & 455 & 8/11 & 1/1 & $0 / 1$ & $\mathrm{nt}$ & 9/13 \\
\hline 5. FLLSLGIHL & POL & 575 & $9 / 13$ & $0 / 1$ & $0 / 1$ & $\mathrm{nt}$ & 9/15 \\
\hline 6. ALMPLYACI & POL & 642 & 2/13 & $0 / 1$ & $0 / 1$ & $\mathrm{nt}$ & 2/15 \\
\hline
\end{tabular}

B A3 supertype peptides

\begin{tabular}{|c|c|c|c|c|c|c|c|}
\hline \multirow[b]{2}{*}{ Peptide } & \multirow[b]{2}{*}{ Protein } & \multirow[b]{2}{*}{ Position } & \multicolumn{5}{|c|}{ CTL responsiveness (No. Pos/No. Tested) } \\
\hline & & & A3 & A11 & A31 & $A * 6801$ & All \\
\hline 7. STLPETTVVRR & CORE & 141 & $0 / 13$ & $1 / 6$ & $3 / 6$ & $4 / 7$ & $8 / 32$ \\
\hline 8. NVSIPWTHK & POL & 47 & $0 / 11$ & $1 / 6$ & $0 / 2$ & $0 / 2$ & $1 / 21$ \\
\hline 9. KVGNFTGLY & POL & 55 & $\mathbf{1} / 11$ & $1 / 6$ & $0 / 2$ & $0 / 3$ & $2 / 22$ \\
\hline 10. HTLWKAGILYK & POL & 149 & $\mathbf{1} / 11$ & $0 / 6$ & $0 / 2$ & $0 / 3$ & $1 / 22$ \\
\hline 11. TLWKAGILYK & POL & 150 & 4/15 & $1 / 9$ & $0 / 2$ & $0 / 2$ & $5 / 28$ \\
\hline 12. LVVDFSQFSR & POL & 377 & $0 / 11$ & $1 / 7$ & $0 / 2$ & $0 / 2$ & $1 / 22$ \\
\hline 13. SAICSVVRR & POL & 520 & $\mathbf{1} / 11$ & $0 / 6$ & $1 / 2$ & $0 / 3$ & $2 / 22$ \\
\hline 14. QAFTFSPTYK & POL & 654 & $2 / 11$ & $1 / 6$ & $0 / 2$ & $0 / 2$ & $3 / 21$ \\
\hline \multicolumn{8}{|l|}{ C B7 supertype peptides } \\
\hline & & & \multicolumn{5}{|c|}{ CTL responsiveness (No. Pos/No. Tested) } \\
\hline Peptide & Protein & Position & B7 & B35 & B51 & B54 & All \\
\hline 15. LPSDFFPSV & CORE & 19 & $0 / 4$ & $0 / 6$ & $2 / 4$ & $0 / 2$ & $2 / 16$ \\
\hline 16. IPIPSSWAF & ENV & 313 & $0 / 3$ & $0 / 3$ & $1 / 4$ & $0 / 2$ & $1 / 12$ \\
\hline 17. TPARVTGGVF & POL & 354 & $0 / 3$ & $1 / 3^{*}$ & $2 / 4 *$ & $0 / 2$ & $2 / 12 *$ \\
\hline 18. HPAAMPHLL & POL & 429 & $0 / 3$ & $0 / 3$ & $0 / 4$ & $0 / 2$ & $0 / 12$ \\
\hline 19. FFPHCLAFSYM & POL & 530 & $0 / 3$ & $0 / 3$ & $0 / 4$ & $0 / 2$ & $0 / 12$ \\
\hline 20. YPALMPLYA & POL & 640 & $0 / 3$ & $0 / 3$ & $0 / 4$ & $0 / 2$ & $0 / 12$ \\
\hline
\end{tabular}

*This peptide was recognized by one patient in a B35- or B51-restricted manner. ${ }^{\ddagger}$ nt indicates not tested.

terminus K159 residue, then the Pol 149-159 and 150-159 peptides might be able to recall potential HLA-A1 restricted responses directed against the same peptide region. As shown in Table V, this is indeed the case since 2 of 10 HLA-A1 positive patients tested for reactivity against the Pol 149-159 and Pol 150-159 peptides displayed $69 \%$ and $16 \%$ HLA-A1 restricted lysis of Pol 149-159 and Pol 150-159 pulsed target cells, respectively.

An even more extreme example of recognition is provided by the HBV Core 18-27 region, which contains two nested epitopes, each capable of degenerate binding in the context of a different HLA class I supertype. In this case nested recognition involves the A2 restricted 18-27 epitope, and the 19-27 peptide that binds multiple B7-supertype molecules with high affinity, especially HLA-B51. As shown in Table IV, 2 of 4 B51-positive patients tested responded to the Core 19-27 peptide while the Core 18-27 peptide was commonly recognized in the context of the A*0201 and A*0205/A*0206 alleles. Table V illustrates representative cytolytic activity specific for these two nested peptides. It is important to note that the B51 restricted CTL that recognized Core 19-27 were unable to kill A*0201 positive target cells pulsed with that peptide (not shown), thus proving that the CTL response to this peptide is indeed restricted by B51.

In sum, degenerate recognition of certain epitopes can occur as a result of the presence of nested class I binding motifs.

Promiscuous CTL recognition of supertype peptides. During the early stage of this study, HLA-A2 positive patients and target cell donors were not subtyped, so A2 positive "matched" target cells were selected for ${ }^{51} \mathrm{Cr}$ release assays based solely on presence of the A2 antigen. After demonstration of the A2supertype, we retrospectively subtyped cryopreserved lymphocytes from our patients and discovered that several experiments had been unknowingly performed with A2-positive effector cells and target cells that were mismatched at the level of A2 subtypes. As shown in Table VI, several of the CTL studied 
Table V. Degenerate Immunogenicity Can Be Expanded by the Presence of Nested HLA Motifs

A Nested epitopes within the HBV Pol 149-159 peptide

\begin{tabular}{|c|c|c|c|c|c|}
\hline \multirow[b]{2}{*}{ Peptide } & \multirow[b]{2}{*}{ Protein } & \multirow[b]{2}{*}{ Position } & \multicolumn{3}{|c|}{$\%$ Specific ${ }^{51} \mathrm{Cr}$ release* } \\
\hline & & & A3 & A11 & A1 \\
\hline HTLWKAGILYK & Pol & 149 & 40 & $-\ddagger$ & 69 \\
\hline TLWKAGILYK & Pol & 150 & 21 & 35 & 16 \\
\hline
\end{tabular}

B Nested epitopes within the HBV core 18-27 peptide

\begin{tabular}{ccccc}
\hline & & & \multicolumn{2}{c}{${ }^{2}$ Specific ${ }^{51}$ Cr release* } \\
\cline { 4 - 5 } Peptide & Protein & Position & $\mathrm{A}^{*} 0201$ & $\mathrm{~B} 51$ \\
\hline FLPSDFFPSV & Core & 18 & 42 & $\mathrm{nt}^{\S}$ \\
LPSDFFPSV & Core & 19 & - & 47
\end{tabular}

* Indicates percentage peptide specific ${ }^{51} \mathrm{Cr}$ release induced by peptidestimulated PBMC from representative patients whose responses were restricted by the HLA alleles shown. ${ }^{*}$ No significant specific release. ${ }^{\S}$ nt, not tested.

displayed promiscuous recognition of their cognate peptides presented in the context of closely related but not homologous HLA alleles. More specifically, A*0201 was able to present at least three different peptides to CTL from four different donors that express the A*0202, A*0205, and A*0206 subtypes. Similarly, we demonstrated that A*0202, A*0205, and/or $A * 0206$, and $A * 0207$ were able to present four different peptides to CTL from 4 different $A * 0201$ positive patients and from two different $A * 0205 / A * 0206$ positive patients.

\section{Discussion}

The present results may have potentially important practical implications for the process of vaccine development. Several reports suggest that the CTL response to HBV appears to play an important role in viral clearance during acute HBV infection $(1-3,8,44)$ and during spontaneous or IFN induced remission of chronic disease (12). The failure of patients with chronic hepatitis to mount a strong CTL response against HBV is thought to be the principal determinant of viral persistence during chronic HBV infection (4). Therapeutic induction of a CTL response to $\mathrm{HBV}$ in chronically infected patients may, therefore, lead to viral clearance. Furthermore, effective immune responses against persistent viruses with high mutation rates, such as $\mathrm{HBV}, \mathrm{HCV}$, and HIV must overcome the potential of viral escape from immune recognition and elimination.

Focusing the immune response towards conserved viral determinants with epitope-based vaccines is a possible means to achieve these goals. In recent studies a synthetic peptide vaccine derived from the highly conserved HLA-A2 restricted HBV Core 18-27 CTL epitope was shown to be immunogenic in A2 positive individuals (40) and a phase II safety and immunogenicity trial of the same vaccine in A2 positive patients with chronic HBV infection is currently underway. Inclusion of several epitopes in a synthetic peptide vaccine would be expected to enhance its efficiency and broaden its specificity. The extreme degree of MHC polymorphism represents a potential obstacle to development of such vaccines, given the complexity of the epitope identification process and the large number of epitopes potentially necessary to achieve broad population coverage.

However, we have recently shown that several HLA class I molecules share overlapping peptide binding specificities, based on recognition of similar main anchor residues (25-29, 50). On this basis, four different supertypes of HLA class I molecules have been defined (25-29), which could permit coverage of well above $90 \%$ of the human population with a relatively small number of peptides, irrespective of the particular ethnicity considered. Until now validation of these concepts in a real disease setting had not been presented. In good agreement with earlier predictions, we have now found that $87-93 \%$ of the patients included in the present study expressed relevant

Table VI. Promiscuous Recognition of HBV-derived Epitopes by CTL in the Context of Nonhomologous HLA Alleles

\begin{tabular}{|c|c|c|c|c|c|c|}
\hline \multirow[b]{2}{*}{ Effector cell HLA } & \multirow[b]{2}{*}{ Patient } & \multirow[b]{2}{*}{ Peptide } & \multicolumn{4}{|c|}{ Target cell HLA (\% Specific ${ }^{51} \mathrm{Cr}$ release)* } \\
\hline & & & $\mathrm{A} * 0201$ & $\mathrm{~A} * 0202$ & $\mathrm{~A} * 0205 / \mathrm{A} * 0206$ & A*0207 \\
\hline \multirow[t]{5}{*}{$A * 0201$} & 3 & FLPSDFFPSV & 27 & $\mathrm{nt}^{\ddagger}$ & $\mathrm{nt}$ & 48 \\
\hline & 4 & FLPSDFFPSV & 34 & $\mathrm{nt}$ & nt & 29 \\
\hline & 5 & FLPSDFFPSV & 35 & 16 & 9 & 6 \\
\hline & 2 & FLLSLGIHL & 36 & $\mathrm{nt}$ & 24 & $\mathrm{nt}$ \\
\hline & 2 & GLSRYVARL & 25 & $\mathrm{nt}$ & 30 & $\mathrm{nt}$ \\
\hline \multirow[t]{2}{*}{$\mathrm{A} * 0202$} & 6 & WLSLLVPFV & 32 & nt & nt & $\mathrm{nt}$ \\
\hline & 6 & GLSRYVARL & 44 & $\mathrm{nt}$ & $\mathrm{nt}$ & $\mathrm{nt}$ \\
\hline \multirow[t]{4}{*}{$\mathrm{A} * 0205 / \mathrm{A} * 0206$} & 7 & FLPSDFFPSV & 100 & 1 & 50 & $\mathrm{nt}$ \\
\hline & 7 & WLSLLVPFV & 85 & 0 & 57 & $\mathrm{nt}$ \\
\hline & 8 & FLPSDFFPSV & 44 & 34 & 20 & 15 \\
\hline & 8 & WLSLLVPFV & 42 & $\mathrm{nt}$ & $\mathrm{nt}$ & $\mathrm{nt}$ \\
\hline \multirow[t]{2}{*}{$A * 0206$} & 9 & FLPSDFFPSV & 15 & $\mathrm{nt}$ & $\mathrm{nt}$ & $\mathrm{nt}$ \\
\hline & 9 & WLSLLVPFV & 95 & $\mathrm{nt}$ & $\mathrm{nt}$ & $\mathrm{nt}$ \\
\hline
\end{tabular}

* Numbers indicate percentage peptide specific ${ }^{51} \mathrm{Cr}$ release induced by peptide-stimulated $\mathrm{PBMC}$ from representative patients whose responses were shown to be restricted by the HLA alleles. Numbers in bold indicate positive responses. ${ }^{\ddagger}$ nt, not tested. 
HLA class I supertype antigens. These results validate the concept that a large fraction of a given patient population can be covered by only a few peptide specificities.

In the present study, we examined a panel of HBV peptides derived from highly conserved regions of the HBV genome for their capacity to bind multiple members of either the A2-, A3-, or B7-supertypes. We found that $63 \%$ of the A*0201 restricted epitopes tested, and $30 \%$ and $71 \%$ of the A3- and B7-supertype peptides tested, respectively, bound at least three out of five of the most common HLA molecules in the appropriate supertype. These results demonstrate that degenerate binding peptides are relatively common, even in conserved regions of human pathogens and can be identified by the use of quantitative binding assays.

Peptides capable of degenerate binding in the context of a given HLA class I supertype were tested for their capacity to elicit specific recall CTL responses from PBL of patients with ongoing acute viral hepatitis or previous HBV infection. Positive CTL responses could be detected for 17 out of $20(85 \%$; see Table IV) of the degenerate binding peptides tested. At least 9 of the 20 peptides tested were immunogenic in the context of multiple MHC types. These results demonstrate that the vast majority of these peptides are actually generated by processing of HBV antigens in the course of a viral infection, and they illustrate that many of these peptides are immunogenic in the context of multiple class I alleles. Degenerate immunogenicity reflected either the ability of a given motif to bind multiple HLA alleles (Table III), or the fortuitous presence of multiple nested HLA motifs within a single short peptide region (e.g., Table V) (49). Promiscuous CTL recognition of a given peptide presented to a given CTL line by multiple HLA specificities was also demonstrated within the A2-supertype for at least four different peptides and four different A2 subtypes (Table VI).

Degenerate class II immunogenicity has been previously demonstrated for epitopes derived from influenza (34-37), plasmodium falciparum (32), tetanus toxoid $(30,51)$, and HBV (33). In some cases degenerate immunogenicity arises from the same peptide (51). In other cases, however, degeneracy arises from the fortuitous presence of different peptide motifs, each binding to different class II types $(30,32,49)$. Our study suggests that both mechanisms are operational in determining degenerate class I restricted immunogenicity. Promiscuous T cell recognition has also been demonstrated for several class II DR-restricted T cell lines and clones (30-36). Our results suggest that promiscuous recognition might be, at least for certain epitopes, also relatively common in the class I system. Thus, the data presented herein highlight a previously unappreciated similarity of class I and class II molecules in terms of the processes of specific, degenerate and/or promiscuous $\mathrm{T}$ cell recognition of peptide-MHC complexes.

In general, immunogenicity correlated with the HLA binding affinity of the peptides. This correlation was not absolute, however, since B51 restricted CTL were observed in the case of the Pol 354 epitope, despite its apparent lack of significant B51 binding capacity. This apparent discrepancy could perhaps be explained by the observation that the Pol 354-362 peptide does bind $\mathrm{B} 51$ with significant, albeit low $\left(\mathrm{IC}_{50}, 4,231 \mathrm{nM}\right)$ affinity. It should also be noted that because of the differential prevalence of HLA alleles in our patient population, certain alleles were more highly represented than others. Therefore, negative results do not necessarily indicate that a peptide is not recognized in the context of a particular allele, especially if it was studied in few patients.

Additionally, a hierarchy of responsiveness, in which A2supertype peptides were the most immunogenic, was apparent. In this hierarchy, A3-supertype peptides exhibited a somewhat intermediate antigenicity pattern, and B7-supertype peptides were the least immunogenic. The higher antigenicity of the A2-supertype peptides probably reflects the fact that these peptides have been extensively prescreened and selected for immunogenicity in HLA A2-positive patients with acute hepatitis, and they have also been shown to induce primary CTL responses in vitro and to be immunogenic in HLA transgenic mice (10). The molecular basis for the observation that a relatively small fraction of individuals expressing A3 and B7 supertype molecules respond to the peptides studied herein is unclear. It might indeed represent a true dominance of A2supertype epitopes over A3 and B7 supertype epitopes. Alternatively, it might suggest that more dominant epitopes were not identified by the current study, either, because they are coded by variable regions of the HBV genome (specifically excluded by our strategy) or because of posttranslational modification of the epitope (52). Nonetheless, demonstration of CTL responsiveness to a given peptide in even one patient establishes that the corresponding epitope is naturally processed during infection. Such epitopes represent candidate targets for immune attack by vaccine-induced CTL. The relatively low frequency of CTL-responsiveness to some of these epitopes does not, therefore, diminish their potential value as components of a therapeutic vaccine. It might even enhance their value if, as subdominant epitopes, they are less likely to be tolerogenic in the course of the patient's chronic HBV infection.

In conclusion, the results presented herein validate the concept of HLA supertypes and supermotifs at the biological level, by illustrating that degenerate HLA binding also results in degenerate immunogenicity for CTL responses in the context of a human disease setting. They may also facilitate development of an epitope based therapeutic vaccine to terminate chronic HBV infection mimicking the multispecificity of HBV specific CTL responses detected in acute hepatitis $\mathrm{B}$, and affording broad and diverse population coverage. Finally, they also predict the development of similar vaccines for the treatment of other chronic viral infections such as HCV and HIV, where generation of a diverse and multispecific response that is focused on highly conserved viral epitopes is likely to be of clinical value.

\section{Acknowledgments}

The authors thank Drs. Paul Pockros (Scripps Clinic), John Person (Balboa Naval Medical Center), Alan Redeker (University of Southern California), Carlo Ferrari (University of Parma, Italy), Ms. Larry Wafer and Mr. Joseph Shaw (Jefferson County Department of Health, Birmingham, AL) for providing patient material; Drs. Gabriele Missale and Barbara Rehermann for preliminary analysis of the CTL response to selected peptides; Scott Southwood, Elissa Keogh for expert technical assistance; the nursing, laboratory and administrative staff of the Scripps General Clinical Research Center for outstanding assistance; and Ms. Jennifer Newmann for assistance with manuscript preparation.

This study was supported by NIH grants AI20001, AI26626 and M01 RR00833, and by NIH contract NO1-AI-45241. This is manuscript number 10477-MEM from The Scripps Research Institute. 


\section{References}

1. Bertoletti, A., C. Ferrari, F. Fiaccadori, A. Penna, R. Margolskee, H.J. Schlicht, P. Fowler, S. Guilhot, and F.V. Chisari. 1991. HLA class I-restricted human cytotoxic $\mathrm{T}$ cells recognize endogenously synthesized hepatitis B virus nucleocapsid antigen. Proc. Natl. Acad. Sci. USA. 88:10445-10449.

2. Nayersina, R., P. Fowler, S. Guilhot, G. Missale, A. Cerny, H.J. Schlicht, A. Vitiello, R. Chesnut, J.L. Person, A.G. Redeker, et al. 1993. HLA A2 restricted cytotoxic T lymphocyte responses to multiple hepatitis B surface antigen epitopes during hepatitis B virus infection. J. Immunol. 150:4659-4671.

3. Missale, G., A. Redeker, J. Person, P. Fowler, S. Guilhot, H.J. Schlicht, C. Ferrari, and F.V. Chisari. 1993. HLA-A31- and HLA-Aw68 restricted cytotoxic $\mathrm{T}$ cell responses to a single hepatitis $\mathrm{B}$ virus nucleocapsid epitope during acute viral hepatitis. J. Exp. Med. 177:751-762.

4. Chisari, F.V., and C. Ferrari. 1995. Hepatitis B virus immunopathogenesis. Annu. Rev. Immunol. 13:29-60.

5. Falk, K., O. Rötzschke, S. Stevanovic, G. Jung, and H-G. Rammensee. 1991. Allele-specific motifs revealed by sequencing of self-peptides eluted from MHC molecules. Nature (Lond.). 351:290-296.

6. Ruppert, J., J. Sidney, E. Celis, R.T. Kubo, H.M. Grey, and A. Sette. 1993. Prominent role of secondary anchor residues in peptide binding to HLAA2.1 molecules. Cell. 74:929-937.

7. Kubo, R.T., A. Sette, H.M. Grey, E. Appella, K. Sakaguchi, N-Z. Zhu, D. Arnott, N. Sherman, J. Shabanowitz, H. Michel, et al. 1994. Definition of specific peptide motifs for four major HLA-A alleles. J. Immunol. 152:3913-3924.

8. Rehermann, B., P. Fowler, J. Sidney, J. Person, A. Redeker, M. Brown, B. Moss, A. Sette, and F.V. Chisari. 1995. The cytotoxic T lymphocyte response to multiple hepatitis B virus polymerase epitopes during and after acute viral hepatitis. J. Exp. Med. 181:1047-1058.

9. Wentworth, P.A., A. Vitiello, J. Sidney, E. Keogh, R.W. Chesnut, H.M. Grey, and A. Sette. 1996. Differences and similarities in the A2.1-restricted cytotoxic $\mathrm{T}$ cell repertoire in humans and human leukocyte antigen-transgenic mice. Eur. J. Immunol. 26:97-101.

10. Sette, A., A. Vitiello, B. Rehermann, P. Fowler, R. Nayersina, W.M. Kast, C.J.M. Melief, C. Oseroff, L. Yuan, J. Ruppert, et al. 1994. The relationship between class I binding affinity and immunogenicity of potential cytotoxic T cell epitopes. J. Immunol. 153:5586-5592.

11. Rehermann, B., C. Ferrari, C. Pasquinelli, and F.V. Chisari. 1996. The hepatitis B virus persists for decades after patient's recovery from acute viral hepatitis despite active maintenance of a cytotoxic T lymphocyte response. $\mathrm{Na}$ ture Med. 2:1104-1108.

12. Rehermann, B., D. Lau, J.H. Hoofnagle, and F.V. Chisari. 1996. Cytotoxic T lymphocyte responsiveness after resolution of chronic hepatitis B virus infection. J. Clin. Invest. 97:1655-1665.

13. Cerny, A., J.G. McHutchison, C. Pasquinelli, M.A. Brothers, P. Fowler, M. Houghton, and F.V. Chisari. 1994. Hepatitis C virus specific cytotoxic T lymphocyte restricted by HLA-A2 are present in the peripheral blood of patients with chronic hepatitis C. In Viral Hepatitis and Liver Disease. K. Nishioka, H. Suzuki, S. Mishiro, and T. Oda, editors. Springer-Verlag, Tokyo. 190-194.

14. Battegay, M., J. Fikes, A.M. Di Bisceglie, P.A. Wentworth, A. Sette, E. Celis, W.-M. Ching, A. Grakoui, C.M. Rice, K. Kurokohchi, et al. 1995. Patients with chronic hepatitis $C$ have circulating cytotoxic $T$ cells which recognize hepatitis C virus-encoded peptides binding to HLA-A2.1 molecules. J. Virol. 69: 2462-2470.

15. Rehermann, B., K-M. Chang, J.G. McHutchison, R. Kokka, M. Houghton, C.M. Rice, and F.V. Chisari. 1996. Differential cytotoxic T-lymphocyte responsiveness to the hepatitis B and C viruses in chronically infected patients. $J$. Virol. 70:7092-7102.

16. Rehermann, B., K.-M. Chang, J.G. McHutchison, R. Kokka, M. Houghton, and F.V. Chisari. 1996. Quantitative analysis of the peripheral blood cytotoxic $\mathrm{T}$ lymphocyte response in patients with chronic hepatitis $\mathrm{C}$ virus infection. J. Clin. Invest. 98:1432-1440.

17. Koshy, R., and G. Inchauspé. 1996. Evaluation of hepatitis C virus protein epitopes for vaccine development. Trends Biotech. 14:364-369.

18. Cease, K.B., and J.A. Berzofsky. 1994. Toward a vaccine for AIDS: the emergence of immunobiology-based vaccine development. Annu. Rev. Immunol. 12:923-989.

19. Vitiello, A., D. Marchesini, J. Furze, L.A. Sherman, and R.W. Chesnut. 1991. Analysis of the HLA-restricted influenza-specific cytotoxic T lymphocyte response in transgenic mice carrying a chimeric human-mouse class I major histocompatibility complex. J. Exp. Med. 173:1007-1015.

20. Bednarek, M.A., S.Y. Sauma, M.C. Gammon, G. Porter, S. Tamhankar, A.R. Williamson, and H.J. Zweerink. 1991. The minimum peptide epitope from the influenza virus matrix protein. Extra and intracellular loading of HLA-A2. J. Immunol. 147:4047-4053.

21. Kast, W.M., R.M.P. Brandt, J. Sidney, J.-W. Drijfhout, R.T. Kubo, H.M. Grey, C.J.M. Melief, and A. Sette. 1994. Role of HLA-A motifs in identification of potential CTL epitopes in human papillomavirus type $16 \mathrm{E} 6$ and E7 proteins. J. Immunol. 152:3904-3912.

22. Celis, E., V. Tsai, C. Crimi, R. DeMars, P.A. Wentworth, R.W. Chesnut, H.M. Grey, A. Sette, and H.M. Serra. 1994. Induction of anti-tumor cytotoxic T lymphocytes in normal humans using primary cultures and synthetic peptide epitopes. Proc. Natl. Acad. Sci. USA. 91:2105-2109.

23. Wang, R.-F., and S.A. Rosenberg. 1996. Human tumor antigens recognized by T lymphocytes: implications for cancer therapy. J. Leukocyte Biol. 60: 296-309.

24. Molldrem, J., S. Dermime, K. Parker, Y. Zheng Jiang, D. Mavroudis, N. Hensel, P. Fukushima, and A.J. Barrett. 1996. Targeted T-cell therapy for human luekemia: cytotoxic $\mathrm{T}$ lymphocytes specific for a peptide derived from proteinase 3 preferentially lyse human myeloid leukemia cells. Blood. 88:24502457.

25. del Guercio, M.-F., J. Sidney, G. Hermanson, C. Perez, H.M. Grey, R.T. Kubo, and A. Sette. 1995. Binding of a peptide antigen to multiple HLA alleles allows definition of an A2-like supertype. J. Immunol. 154:685-693.

26. Sidney, J., M.-F. del Guercio, S. Southwood, V.H. Engelhard, E. Appella, H-G. Rammensee, K. Falk, O. Rötzschke, M. Takiguchi, R.T. Kubo, et al. 1995. Several HLA alleles share overlapping peptide specificities. J. Immunol. 154:247-259.

27. Sidney, J., H.M. Grey, S. Southwood, E. Celis, P.A. Wentworth, M.-F. del Guercio, R.T. Kubo, R.W. Chesnut, and A. Sette. 1996. Definition of an HLA-A3-like supermotif demonstrates the overlapping peptide-binding repertoires of common HLA molecules. Hum. Immunol. 45:79-93.

28. Sidney, J., S. Southwood, M.-F. del Guercio, H.M. Grey, R.W. Chesnut, R.T. Kubo, and A. Sette. 1996. Specificity and degeneracy in peptide binding to HLA-B7-like class I molecules. J. Immunol. 157:3480-3490.

29. Sidney, J., H.M. Grey, R.T. Kubo, and A. Sette. 1996. Practical, biochemical and evolutionary implications of the discovery of HLA class I supermotifs. Immunol. Today. 17:261-266.

30. Panina-Bordignon, P., A. Tan, A. Termijtelen, S. Demotz, G. Corradin, and A. Lanzavecchia. 1989. Universally immunogenic T cell epitopes: promiscuous binding to human MHC class II and promiscuous recognition by T cells. Eur. J. Immunol. 19:2237-2242.

31. Alexander, J., J. Sidney, S. Southwood, J. Ruppert, C. Oseroff, A. Maewal, K. Snoke, H.M. Serra, R.T. Kubo, A. Sette, et al. 1994. Development of high potency universal DR-restricted helper epitopes by modification of high affinity DR-blocking peptides. Immunity. 1:751-761.

32. Sinigaglia, F., M. Guttinger, J. Kilgus, D.M. Doran, H. Matile, H. Etlinger, A. Trzeciak, D. Gillessen, and J.R.L. Pink. 1988. A malaria T-cell epitope recognized in association with most mouse and human MHC class II molecules. Nature (Lond.). 336:778-780.

33. Ferrari, C., A. Bertoletti, A. Penna, A. Cavalli, A. Valli, G. Missale, M. Pilli, P. Fowler, T. Giuberti, F.V. Chisari, et al. 1991. Identification of immunodominant $\mathrm{T}$ cell epitopes of the hepatitis $\mathrm{B}$ virus nucleocapsid antigen. $J$. Clin. Invest. 88:214-222.

34. Alexander, J., K. Snoke, J. Ruppert, J. Sidney, M. Wall, S. Southwood, C. Oseroff, T. Arrhenius, F.C.A. Gaeta, S.M. Colón, et al. 1993. Functional consequences of engagement of the T cell receptor by low affinity ligands. J. Immunol. 150:1-7.

35. Snoke, K., J. Alexander, A. Franco, L. Smith, J.V. Brawley, P. Concannon, H.M. Grey, A. Sette, and P. Wentworth. 1993. The inhibition of different $\mathrm{T}$ cell lines specific for the same antigen with TCR antagonist peptides. J. Immunol. 151:6815-6821.

36. Krieger, J.I., R.W. Karr, H.M. Grey, W.-Y. Yu, D. O'Sullivan, L. Batovsky, Z.-L. Zheng, S.M. Colón, F.C.A. Gaeta, J. Sidney, et al. 1991. Single amino acid changes in DR and antigen define residues critical for peptide-MHC binding and $\mathrm{T}$ cell recognition. J. Immunol. 146:2331-2340.

37. Rothbard, J.B., R.I. Lechler, K. Howland, V. Bal, D.D. Eckels, R. Sekaly, E.O. Long, W.R. Taylor, and J.R. Lamb. 1988. Structural model of HLA-DR1 restricted T cell antigen recognition. Cell. 52:515-523.

38. Oldstone, M.B.A., A. Tishon, R. Geckeler, H. Lewicki, and J.L. Whitton. 1992. A common antiviral cytotoxic T-lymphocyte epitope for diverse major histocompatibility complex haplotypes: Implications for vaccination. Proc. Natl. Acad. Sci. USA. 89:2752-2755.

39. Zinkernagel, R.M., and P.C. Doherty. 1974. Restriction of in vitro T cell-mediated cytotoxicity in lymphocytic choriomeningitis virus within a syngeneic or semiallogeneic system. Nature (Lond.). 248:701-703.

40. Vitiello, A., G. Ishioka, H.M. Grey, R. Rose, P. Farness, R. LaFond, L. Yuan, F.V. Chisari, J. Furze, R. Bartholomeuz, et al. 1995. Development of a lipopeptide-based therapeutic vaccine to treat chronic HBV infection. J. Clin. Invest. 95:341-349.

41. Pasek, M., T. Goto, W. Gilbert, B. Zink, H. Schaller, P. Mackay, G. Leadbetter, and K. Murray. 1979. Hepatitis B virus genes and their expression in E. coli. Nature (Lond.). 282:575.

42. Sette, A., J. Sidney, M.-F. del Guercio, S. Southwood, J. Ruppert, C. Dahlberg, H.M. Grey, and R.T. Kubo. 1994. Peptide binding to the most frequent HLA-A class I alleles measured by quantitative molecular binding assays. Mol. Immunol. 31:813-822.

43. Guilhot, S., P. Fowler, G. Portillo, R.F. Margolskee, C. Ferrari, A. Bertoletti, and F.V. Chisari. 1992. Hepatitis B virus (HBV)-specific cytotoxic T cell response in humans: Production of target cells by stable expression of HBVencoded proteins in immortalized human B-cell lines. J. Virol. 66:2670-2678.

44. Penna, A., F.V. Chisari, A. Bertoletti, G. Missale, P. Fowler, T. Giuberti, F. Fiaccadori, and C. Ferrari. 1991. Cytotoxic T lymphocytes recognize an HLA-A2-restricted epitope within the hepatitis B virus nucleocapsid antigen. $J$. 
Exp. Med. 174:1565-1570.

45. Ferrie, R.M., M.J. Schwarz, N.H. Robertson, S. Vaudin, M. Super, G. Malone, and S. Little. 1992. Development, multiplexing, and application of ARMS tests for common mutations in the cFTR gene. Am. J. Hum. Genet. 51:251-262. 46. Zemmour, J., and P. Parham. 1992. HLA class I nucleotide sequences. Tissue Ant. 40:221-228.

47. Fernandez-Viña, M.A., M. Falco, Y. Sun, and P. Stastny. 1992. DNA typing for HLA class I alleles. I. Subsets of HLA-A2 and of -A28. Hum. Immunol. 33:163-173.

48. Celis, E., D. Ou, and L. Otvos. 1988. Recognition of hepatitis B surface antigen by human $\mathrm{T}$ lymphocytes. Proliferative and cytotoxic responses to a major antigenic determinant defined by synthetic peptides. J. Immunol. 140: $1808-1815$

49. Berzofsky, J.A., C.D. Pendleton, M. Clerici, J. Ahlers, D.R. Lucey, S.D.
Putney, and G.M. Shearer. 1991. Construction of peptides encompassing multideterminant clusters of HIV envelope to induce in vitro T Cell responses in mice and humans of multiple MHC types. J. Clin. Invest. 88:876-884.

50. Barber, L.D., B. Gillece-Castro, L. Percival, X. Li, C. Clayberger, and P. Parham. 1995. Overlap in the repertoires of peptides bound in vivo by a group of related class I HLA-B allotypes. Curr. Top. Biol. 5:179-190.

51. O’Sullivan, D., J. Sidney, M.-F. del Guercio, S.M. Colón, and A. Sette. 1991. Truncation analysis of several DR binding epitopes. J. Immunol. 146 $1240-1246$.

52. Meadows, L., W. Wang, J.M.M. den Haan, E. Blokland, C. Reinhardus, J.W. Drijfhout, J. Shabanowitz, R. Pierce, A.I. Agulnik, C.E. Bishop, et al. 1997 The HLA-A*0201-Restricted H-Y antigen contains a posttranslationally modified cysteine that significantly affects T cell recognition. Immunity. 6:273-281. 